I am grateful to Professors A L Bloom and M S J Pathy for their permission to report details of their patients and particularly to Sister A Jackson and the staff of the day theatre for their help with the endoscopic procedures.

1 Goff JS. Bipolar electrocoagulation versus Nd-YAG laser photocoagulation for upper gastrointestinal bleeding lesions. Dig Dis Sci 1986;31:906-10.

2 Wheeler MH, Smith PM, Cotton PB, et al. Abnormal blood vessels in the gastric antrum. Dig Dis Sci 1979;24:155-8.

3 Weaver GA, Alpern HD, Davis JS, et al. Gastrointestinal angiodysplasia associated with aortic valve disease: part of a spectrum of angiodysplasia of the gut. Gastroenterology 1979;77:1-11.

4 Bown SG, Swain CP, Storey DW, et al. Endoscopic laser treatment of vascular anomalies of the upper gastrointestinal tract. Gut 1985;26:1338-48.

5 Hajiro K, Matsui H, Tsujimura D. Endoscopic hemostasis with hemoclips, local injection and other new techniques: the Japanese experience. Endoscopy 1986;18(suppl 2):65-7.

(Accepted 27 March 1987)

University Hospital of Wales, Cardiff CF4 4XW

JAMES D R ROSE, MA, MD, senior registrar in gastroenterology

\section{Safety and acceptability of condoms for use by homosexual men as a prophylactic against transmission of HIV during anogenital sexual intercourse}

In the Western world the human immunodeficiency virus, which causes the acquired immune deficiency syndrome (AIDS) and AIDS related conditions, is transmitted mainly by anogenital sexual intercourse between men. ${ }^{12}$ Since prevention of transmission is at present the only way of controlling the epidemic prevention programmes should be aimed at homosexual men. Information campaigns have resulted in some change in sexual behaviour among homosexual men (reports of Amsterdam municipal health service, 1984-7), but additional measures are required. Condoms may prove to be an acceptable and worthwhile means of preventing transmission of the virus during sexual intercourse since the human immunodeficiency virus cannot penetrate the intact membrane of latex condoms (S Sprecher, personal communication). Homosexual men, however, are not accustomed to using prophylactic measures during sexual intercourse. Condoms must therefore be made acceptable for this group. Also because of the greater friction during anogenital intercourse the condoms must be stronger than normal. We studied 17 male homosexual couples to assess the acceptability and safety of different types of condoms.

\section{Subjects, methods, and results}

Seventeen male homosexual couples responded to an advertisement in a gay magazine inviting steady couples to participate in a study on the acceptability of condoms. Their respresentativeness was not important since anogenital intercourse is the main risk factor for transmission of the human immunodeficiency virus in homosexual men. None of the participants had used condoms regularly before. Seven different combinations of condom and lubricants were tested twice by each couple (table). They were not told about the differences between the condoms, which were designed specially for this study, nor did they know about the different quantities of lubricant supplied. It was agreed that the same partner should take the insertive-that is, penetrating - role in all test sessions. Both the insertive and the receptive partners recorded their experiences on a precoded questionnaire immediately after each test session. After the survey all insertive partners were interviewed about their overall impression.
Not all combinations of condom and lubricant were tested twice by all couples. The couples had been told that the overall impression depended on mechanical aspects - that is, size, fit, strength, risk of slipping off during use, and amount of lubricant-and one important psychological factor-appearance. Of the insertive partners, $40 \%$ found the use of condoms unpleasant and $26 \%$ appreciated them; $34 \%$ were indifferent. Condoms S, A, and T were the least likely to rupture during use $(0,3$, and $10 \%$ of test sessions); this seemed to be related to inflation volume and stiffness (table). Of these condoms, only $S$ did not slip off at all. Condom $S$ therefore met the safety requirements best. According to the questionnaires, the acceptability of condoms was reduced by bad fit and stiffness, as well as by inadequate lubricant and the unnatural appearance-that is, squeezing-of the penis in the condom. These factors were closely related to the extent to which sensitivity was affected by wearing a condom. The stiffest condoms, S, A, and T, were the most uncomfortable. Overall acceptability of the condoms was low: in all test sessions (200) they were considered unattractive by $68 \%$ of the insertive partners and $55 \%$ of the receptive partners (for condom $S$ the corresponding figures were 78 and $68 \%$ of 23 sessions; for condom A 69 and $53 \%$ of 58 sessions; and for condom T 75 and $63 \%$ of 30 sessions). The presence of lubricant on the condoms was not liked, and in most cases there was not enough. All participants preferred condoms of a neutral appearance which affected the natural situation as little as possible.

\section{Comment}

Of all the condoms studied $\mathrm{S}$ was clearly the safest. In general, the stiffest condoms seemed to be safer than the others, but they were also the least liked and therefore unacceptable to the participants. Changes are necessary for the successful introduction of condoms as a prophylactic against transmission of the human immunodeficiency virus in male homosexuals. Condom S may be used as a starting point for the production of preformed condoms in different sizes which do not "squeeze" the penis and hence do not cause an unnatural appearance. The semen reservoir, a disturbing and unnecessary addition, should be omitted, and lubricant must be supplied separately and in sufficient quantity.

We have discussed the relative safety of several condoms-that is, the chance of rupturing and slipping off during use-and their acceptability to male homosexuals. We have not, however, answered the question whether condoms offer complete protection. Since this can never be guaranteed, they should be used with restraint. Changes in sexual behaviour remain the main goal.

We thank the Dutch division of the London Rubber Company for providing the condoms and their specifications and the Dutch Society for Sexual Reform for specifications.

Addendum. The Dutch division of the London Rubber Company has introduced a condom which meets most of the recommendations made above.

1 Griensven GJP van, Tielman RAP, Goudsmit J, et al. Risikofactoren en prevalentie van LAV/HTLV-III antistoffen bij homoseksuele mannen in Nederland. Tijdschrift voor Sociale Gezondheidszorg 1986;64: 100-7.

2 Peterman TA, Drotman DP, Curran JW. Epidemiology of the acquired immune deficiency syndrome. Epidemiol Rev 1985;7:1-21.

(Accepted 9 April 1987)

Department of General Practice, Academic Medical Centre, University of Amsterdam, Amsterdam, The Netherlands

LODE WIGERSMA, MD, general practitioner, teacher, and research assistant

Faculty of Medicine, Academic Medical Centre, University of Amsterdam, Amsterdam, The Netherlands

RON OUD, medical student

Correspondence to: L Wigersma, Instituut voor huisartsgeneeskunde, Academisch Medisch Centrum, Meibergdreef 15, 1105 AZ Amsterdam, The Netherlands.

Specifications and subjective assessment of condoms and lubricant

\begin{tabular}{|c|c|c|c|c|c|c|c|c|c|c|c|c|c|}
\hline \multirow[b]{3}{*}{ Condom } & \multirow[b]{3}{*}{$\begin{array}{l}\text { Quantity of } \\
\text { lubricant (g) }\end{array}$} & \multicolumn{4}{|c|}{ Specifications } & \multicolumn{8}{|c|}{ Appreciation by insertive partners (No (\%) of test sessions) } \\
\hline & & \multirow[b]{2}{*}{$\begin{array}{c}\text { Membrane } \\
\text { thickness } \\
(\mu \mathrm{m})\end{array}$} & \multirow[b]{2}{*}{$\begin{array}{l}\text { Inflation } \\
\text { volume (l) }\end{array}$} & \multirow[b]{2}{*}{$\begin{array}{l}\text { Drawing } \\
\text { strength } \\
(\mathbf{M P a})\end{array}$} & \multirow[b]{2}{*}{ Stiffness } & \multirow[b]{2}{*}{$\begin{array}{l}\text { No of test } \\
\text { sessions }\end{array}$} & \multirow[b]{2}{*}{ Rupture } & \multirow[b]{2}{*}{ Slipped off } & \multirow[b]{2}{*}{ Too small } & \multirow[b]{2}{*}{$\begin{array}{l}\text { Reduced } \\
\text { sensitivity }\end{array}$} & \multirow[b]{2}{*}{$\begin{array}{l}\text { Unattrac- } \\
\text { tive } \\
\text { appearance }\end{array}$} & \multicolumn{2}{|c|}{ Overall appreciation } \\
\hline & & & & & & & & & & & & $\begin{array}{c}\text { Bad } \\
(\text { mean } 40 \%)\end{array}$ & $\begin{array}{c}\text { Good } \\
(\text { mean } 26 \%)\end{array}$ \\
\hline $\begin{array}{l}\text { A } \\
\text { A }\end{array}$ & $\begin{array}{l}1.0 \\
0.85\end{array}$ & $\begin{array}{l}100 \\
100\end{array}$ & $\begin{array}{l}34 \cdot 8 \\
34 \cdot 8\end{array}$ & $\begin{array}{l}29 \cdot 2 \\
29 \cdot 2\end{array}$ & $\begin{array}{l}++ \\
++\end{array}$ & 58 & $1(2)$ & $7(12)$ & $27(46)$ & $41(71)$ & $40(69)$ & $22(38)$ & $13(22)$ \\
\hline B & $1 \cdot 0$ & 80 & $26 \cdot 6$ & $35 \cdot 3$ & + & 60 & $13(22)$ & $8(14)$ & $24(42)$ & $36(60)$ & $38(63)$ & $22(37)$ & $16(26)$ \\
\hline $\begin{array}{l}\mathbf{B} \\
\mathbf{T}\end{array}$ & 0.85 & $\begin{array}{r}80 \\
120\end{array}$ & $\begin{array}{l}26 \cdot 6 \\
27 \cdot 4\end{array}$ & $\begin{array}{l}35 \cdot 3 \\
33 \cdot 6\end{array}$ & $\begin{aligned} t \\
+t\end{aligned}$ & 30 & $(3)$ & $3(23)$ & $14(15)$ & $21(70)$ & & $15(50)$ & \\
\hline S & 0.7 & 80 & $\begin{array}{l}21.4 \\
30.6\end{array}$ & $\begin{array}{l}35.6 \\
36.8\end{array}$ & $\begin{array}{r}++ \\
+++\end{array}$ & $\begin{array}{l}30 \\
23\end{array}$ & $\begin{array}{l}T(3) \\
0(0)\end{array}$ & $\begin{array}{c}10(33) \\
0(0)\end{array}$ & $\begin{array}{l}14(45) \\
15(65)\end{array}$ & $\begin{array}{l}21(70) \\
17(74)\end{array}$ & $\begin{array}{l}22(75) \\
18(78)\end{array}$ & $\begin{array}{r}15(50) \\
9(39)\end{array}$ & $\begin{array}{r}10(33) \\
6(26)\end{array}$ \\
\hline G & 0.7 & 48 & $19 \cdot 6$ & $30 \cdot 6$ & - & 29 & $6(20)$ & $5(17)$ & $9(30)$ & $15(30)$ & $18(60)$ & $14(45)$ & $6(21)$ \\
\hline
\end{tabular}

